ENSV TEADUSTE AKADEEMIA TOIMETISED. XVI KOIDE

KEEMIA * GEOLOOGIA. 1967, Nr. 2

ИЗВЕСТИЯ АКАДЕМИИ НАУК ЭСТОНСКОИ ССР. ТОМ ХVI

ХимИЯ * ГЕОЛОГИЯ. 1967, №2 2

А. ЭЛЕНУРМ, Т. ЛАУС, М. ГУБЕРГРИЦ

\title{
МАКРОКИНЕТИКА ПРОЦЕССА ПИРОЛИЗА СЛАНЦЕВЫХ БЕНЗИНОВ В КИПЯЩЕМ СЛОЕ
}

\begin{abstract}
Существенное повышение эффективности комплексного энергохимнческого использованд̆ сланца-кукерсита может быть достигнуто при сочетании процессов полукоксования этого топлива с термической конверсией (пиролизом) получаемых нестабильных и низкооктановых бензинов. В процесс пиролиза может быть дополнительно вовлечена средняя фракция сланцевой смолы или отходы ее химической переработки. Это сырье отличается специфическим химическим составом $[1,2]$ и известной склонностью к коксообразованию.

Исходя из сказанного, несомненными достоинствами обладает метод термоконтактного пиролиза в кипящем слое твердого теплоносителя, который отличается также высокой интенсивностью процессов тепло- и массообмена. Он получил широкое распространение и хорошо изучен применительно к конверсии различных видов парафинистого нефтяного сырья. Сведения же о макрскинетических и термодинамических особенностях такого процесса применительно к столь своеобразному сырью, как сланцевое, весьма ограничены.

В настоящем сообщении изложены и обсуждены результаты первого этапа исследования термоконтактного пиролиза сланцевых бензинов, проведенного в указанном аспекте на лабораторной стендовой установке непрерывного действия.
\end{abstract}

\section{Методика и результаты исследования}

Схема экспериментальной установки приведена на рис. 1. Основную ее часть составляет пиролизер, в нижней части которого расположена собственно реакционная зона. С помощью питающей форсунки в зону вводится смесь бензинового сырья и перегретого водяного пара. В верхней расширенной части пиролизера в результате резкого снижения скорости потоков происходит отделение взвешенного твердого материала (теплоносителем служит фракция кварцевого песка крупностью $0,4-$ 0,8 мM).

Величина критической скорости начала псевдоожижения, обусловливающая стабильное ведение процесса в кипящем слое, спределена по известной формуле Лева ${ }^{[3]}$ с учетом рекомендаций ряда других исследователей [4,5]. Она составляет в данном случае 9,0 см/сек (в расчете на свободное сечение аппарата). Высота неподвижного слоя зернистого материала во всех опытах поддерживалась на практически неизменном уровне - около 170 м..

Заданный температурный режим обеспечивался системой внешнего электрообогрева. Перепад температуры между нижней - реакционной и верхней - закалочной и отделительной зонами аппарата поддерживался на уровне $200-250^{\circ} \mathrm{C}$. 


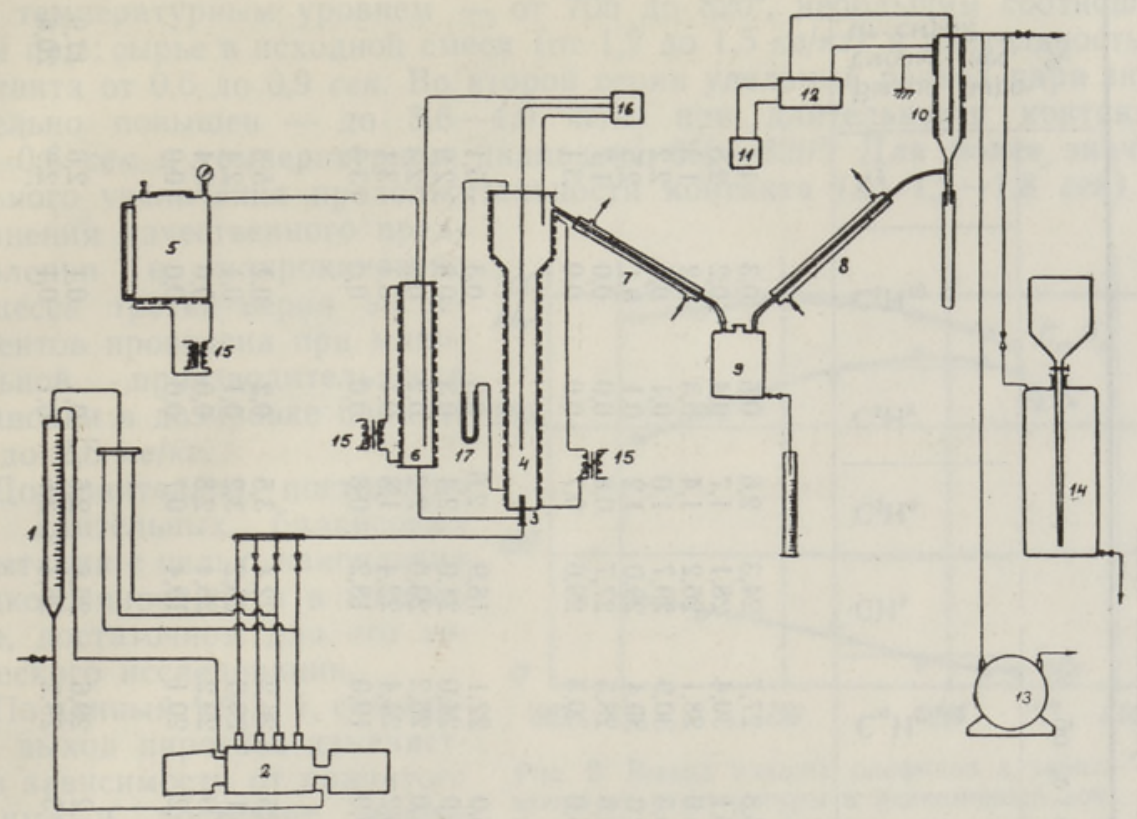

Рис. 1. Схема экспериментальной устзновки:

1 - приемник сырья; 2 - насос; 3 - форсунка; 4 - пиролизер; 5 - парогенератор: 6 - перегреватель пара; 7,8 - холодильники; 9 - приемник конденсата; 10 электрофильтр для улавливания пиробензина: 11 - аккумулятор; 12 - катушка Румкорфа; 13 - газовый счетчик; 14 - аспиратор; 15 - автотрансформаторы; 16 - милливольтметр; 17 - днфференциальный манометр.

При проведении исследования использованы два вида сланцевого сырья: фракция бензина из туннельных печей с верхним пределом кипения $150^{\circ}$ (потенциальный остаток после выделения сырья для химического синтеза) и бензиновая фракция суммарной смолы из опытно-промышленной установки с твердым теплоносителем (УТТ) - отгон фракции с верхним пределом кипения $200^{\circ}$ из легкосреднего масла. Наладочные опыты проведены на легком нефтяном бензине, контрольные исследования - с индивидуальными модельными веществами н-октаном и н-додеканом.

Первый вид изученного сырья характеризуется плогностью $\varrho_{4}^{20}=0,755$ и молекулярным весом $M=98$. Его групповой химический состав (вес. \%): углеводороды $\mathrm{C}_{3}+\mathrm{C}_{4}-1,3$; парафины $-25,0$; нафтены $-17,6$; н-олефины $-37,4$; циклоолефины 4,2 , неидентифицированные - 4,5; ароматические углеводороды отсутствуют.

Бензиновое сырье из УТТ $\left(\varrho_{4}{ }^{20}=0,785 ; M=107\right)$ отличается от первого вида своим групповым химическим составом (вес. \%): углеводороды $\mathrm{C}_{3}+\mathrm{C}_{4}-1,0$; парафины - 13,8 ; нафтены - 3,9 ; н-олефины - 42,5; циклоолефины -- 1,5 ; ароматические углеводороды - 23,8 ; неидентифицированные - $13,5 . *$

Из приведенных данных видно, что второе сырье отличается от первого повышенным содержанием ароматическнх углеводородов и пониженным - парафннов и циклоолефинов.

Исследование процесса термоконтактного пиролиза легкой части бензина туннельных печей проведено при варьировании условий в трех сериях опытов (табл. 1). Первая из них отличается сравнительно высо-

* Исследование состава сырья (так же, как и жидкого пиролизата, см. ниже) произведено на хроматографе УХ-I M. Воллем. 
ฮู

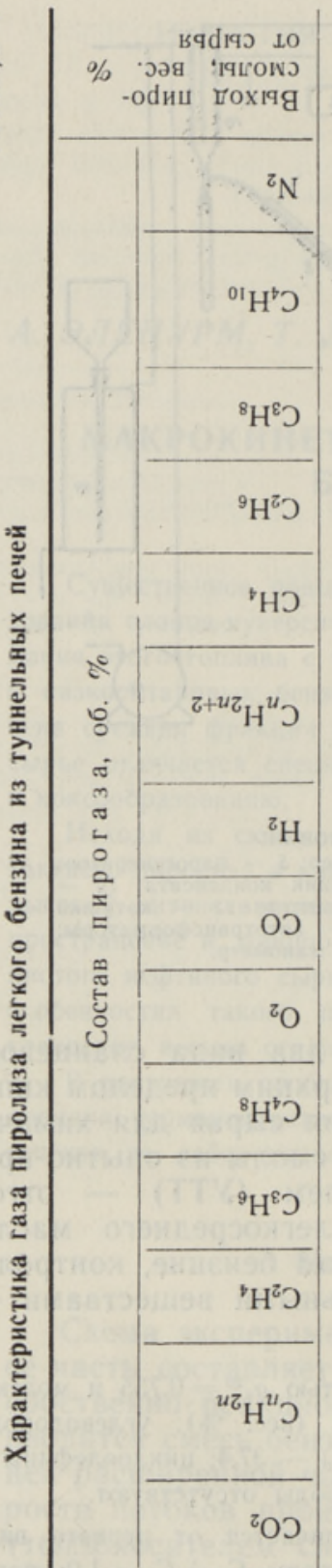

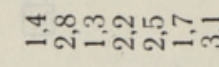

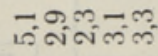

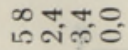

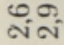

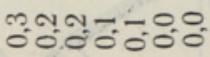

ตัตูอ์

둥응

$\overrightarrow{0} \overline{0}$

0.0000000

mon-0:0

200000

:-5

ติ-

N $\operatorname{Tin} \infty \infty$

เอำก

งิ

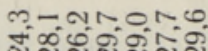

कọ 0 -

सथ

$\infty+$

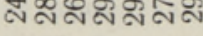

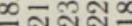

สูกะัตำ

ลัก

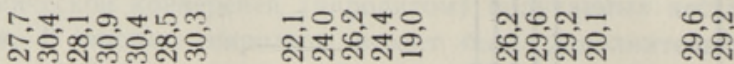

n-0, Ono OONO

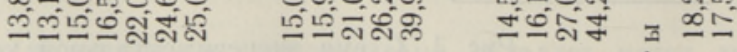

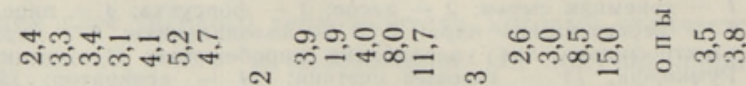

$\pi$

$=\sqrt{x}$

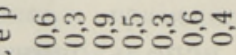

บั

a

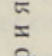

$m \infty n-$

- -1200

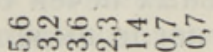

nomoo

काष्०

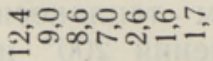

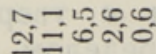

0000.

बiका-

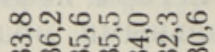

O. $0.5,0.0$

Nonm

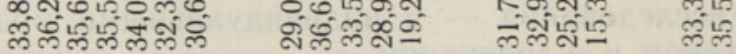

018

$\infty, \infty \infty, 0,0$

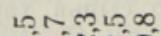

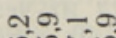

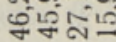

เi:

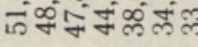

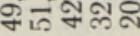

חี

$=\infty$ 인ำ

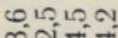

केष

2x/v 'eEe. Ifoxiqg

уวว

'BLYELHOY BWadg

23/कx 'วqdıว : deш әинәтон $\mathrm{O}$

ว。 'edאцedəuพว $\mathrm{L}$.
品

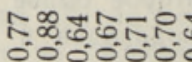

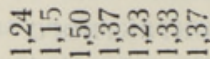

ming

ำํํ요

ำกำ

$\vec{\infty} \infty$

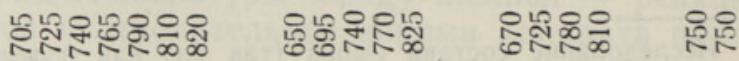


ким температурным уровнем - от 705 до $820^{\circ}$, небольшим соотношением пар : сырье в исходной смеси (от 1,2 до 1,5 к2/к2) и длительностью контакта от 0,6 до 0,9 сек. Во второй серии удельный расход пара значительно повышен - до 3,6-4,0 к2/к2 при длительности контакта $0,5-0,6$ сек и температурном диапазоне $650-820^{\circ}$. Для более значительного увеличения продолжительности контакта (до 1,2-1,8 сек) и уточнения качественного представления о. макрокинетике процесса третья-серия экспериментов проведена при минимальной производительности установки в дозировке пара от 1,8 до 2,8 ка/ка.

Дополнительно поставлено два длительных балансовых испытания с целью накопления жидкого пиролизата в количестве, достаточном для его химического исследования.

По данным табл. 1, суммарный выход пирогаза изменяется в зависимости от принятого режима и достигает максимального значения (1356 $几 / \kappa 2)$ при температуре $825^{\circ}$. При относительно пониженной темпе-

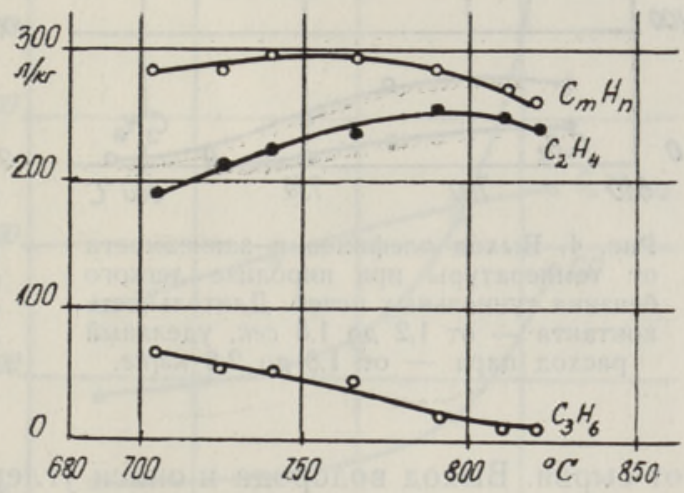

Рис. 2. Выход низших олефинов в зависимости от температуры в реакционной зоне. Пиролиз легкого бензина туннельных печей; длительность контакта - от 0,6 до 0,9 сек, удельный расход пара от 1,2 до $1,5 \mathrm{\kappa} 2 / \kappa 2$. ратуре процесса в составе пирогаза преобладают низшие олефиновые углеводороды; так, при $705^{\circ}$ их суммарная доля составляет 51,8 об.\% (в том числе до $36,6 \%$ этилена).

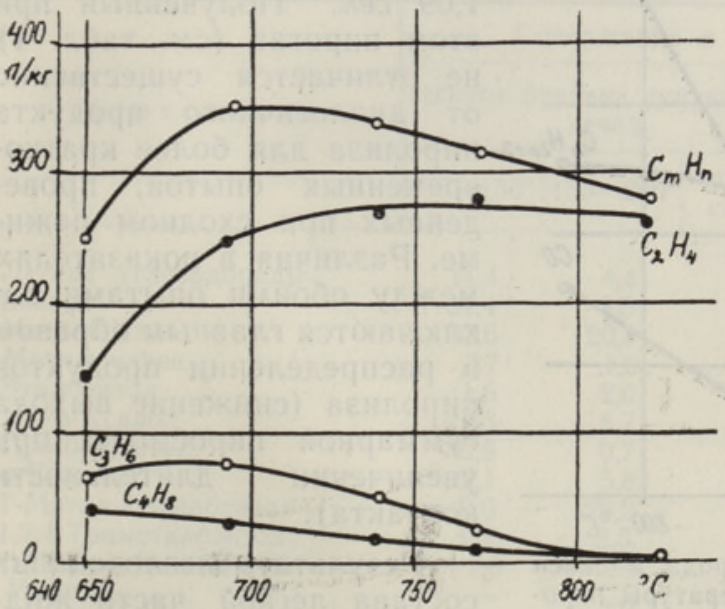

Рис. 3. Выход олефинов в зависимости от температуры при пиролизе легкого бензина туннельных печей. Длительность контакта - от 0,5 до 0,6 сек, удельный расход пара - от 3,6 до $4,0 \mathrm{\kappa z} / \mathrm{\kappa 2}$.

С ростом температуры концентрация олефинов (особенно высших гомологов) в газе значительно падает. Одновременно растет содержание водорода и окиси углерода.

Как видно из рис. 2-4, оптимальные результаты с точки зрения суммарного выхода непредельных, в том числе этилена, соответствуют условиям второй серии, то есть высокому разбавлению сырья паром и кратковременному контакту. Наиболее значителен их выход (52,4 вес. \% от сырья) при температуре в реакционной зоне около $695^{\circ}$. Максимальный же выход этилена, как и следовало ожидать, набльдается при более высокой температуре $\left(770^{\circ}\right)$.

Температурная зависимость выхода предельных компонентов в:пирогазе (рис. 5-7) мало изменяется при варьировании условий ведения процесса. При температуре $825^{\circ}$ их суммарный выход определен в $19,2 \%$ 


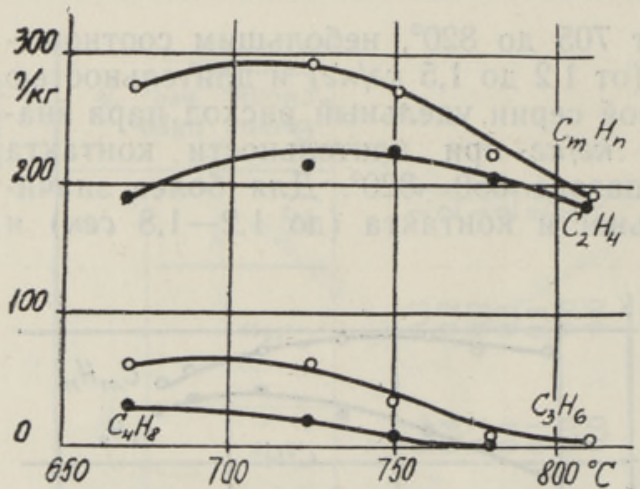

Рнс. 4. Выход олефинов в зависимости от температуры при пиролизе легкого бензина туннельных печей. Длительность контакта - от 1,2 до 1,8 сек, удельный расход пара - от 1,8 до 2,8 ка/к2.

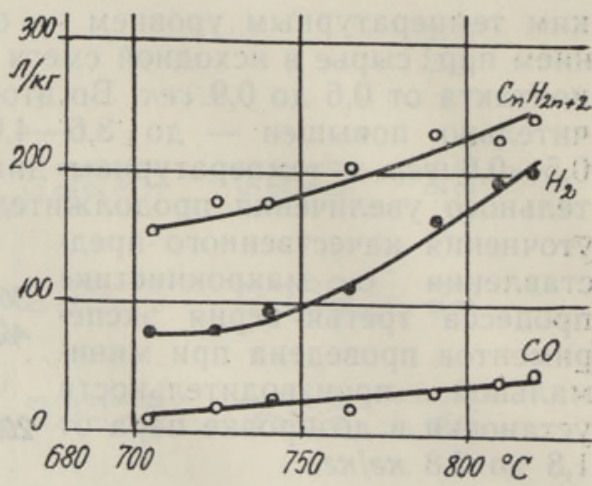

Рис. 5. Выход парафинов, водорода и окиси углерода в зависимости от температуры при пиролизе легкого бензина туннельных печей. Первая серия опытов (см. рис. 2).

от сырья. Выход водорода и окиси углерода при повышенной дозировке пара в исходной смеси резко увеличивается начиная с $750^{\circ}$. Снижение доли пара в сырьевой смеси ослабляет рост выхода этих «вторичных» компонентов при подъеме температуры (рис. 7).

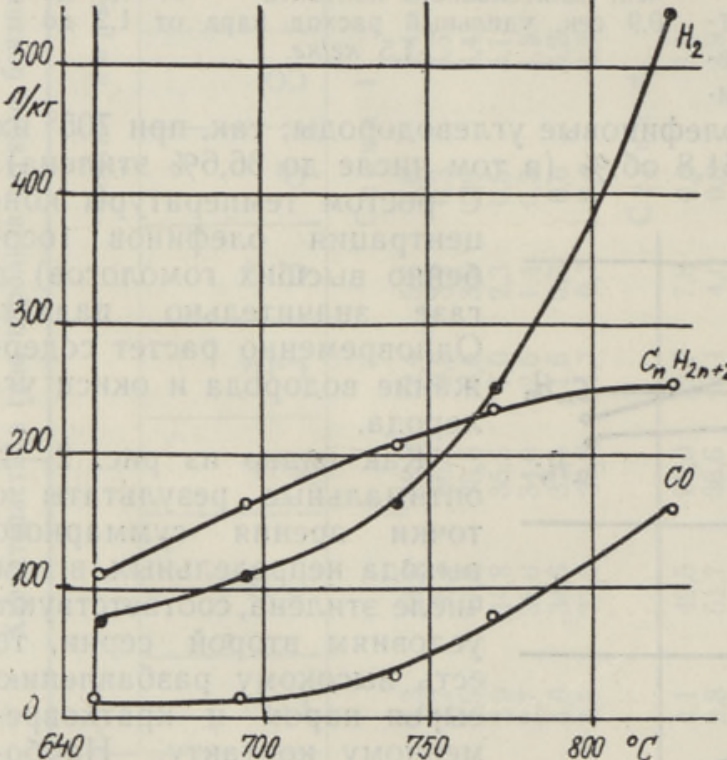

Рис. 6. Выход парафинов, водорода и окиси углерода в зависимости от температуры пиролиза. Вторая серия опытов (см. рис. 3).

Балансовые опыты в первой серии проведены при температурном потенциале процесса $750^{\circ}$, удельном расходе пара 1,8 к2/к2 и длительности контакта 1,22 и 1,09 сек. Полученный при этом пирогаз (см. табл. 1) не отличается существенно от аналогичного продукта пиролиза для более кратковременных опытов, проведенных при сходном режнме. Различия в показателях между обоими опытами заключаются главным образом в распределении продуктов пиролиза (снижение выхода суммарной пиросмолы при увеличении длительности контакта).

Результаты исследования состава легкой части жидкого пиролизата свидетельствуют о практически полной ее ароматизации (табл. 2).

Во фракции с пределами кипения 95-150 преобладаюгцими компонентами являются бензол и метилбензол (в сумме - 60,3 и 64,0\%); во фракции $150-200^{\circ}$ жидкого пиролизата особенно высоко содержание метилбензола и 1-метил-2-этилбензола.

Аналогичные макрокинетические исследования процесса пиролиза бензиновой фракции из агрегата с твердым теплоносителем проведены 
в двух сериях с варьированием дозировки пара в исходной смеси и длительности контакта (табл. 3 и 4). По основным качественным закономерностям полученные результаты мало отличаются от данных первого цикла исследования. Однако изменение качества сырья сказывается на ряде количественных показателей. Содержание низших олефинов в пирогазе достигает максимума $(46,4 \%)$ при температуре пиролиза $655^{\circ}$, причем выход этилена составляет $37,4 \%$. Максимальный выход последнего зафиксирован при температуре в реакционной зоне около $680^{\circ}$ и дозировке пара 3,5 кг/ка (31,6 вес.\%). Снижение степени разбавления сырья паром влечет за собой падениє выхода этилена.

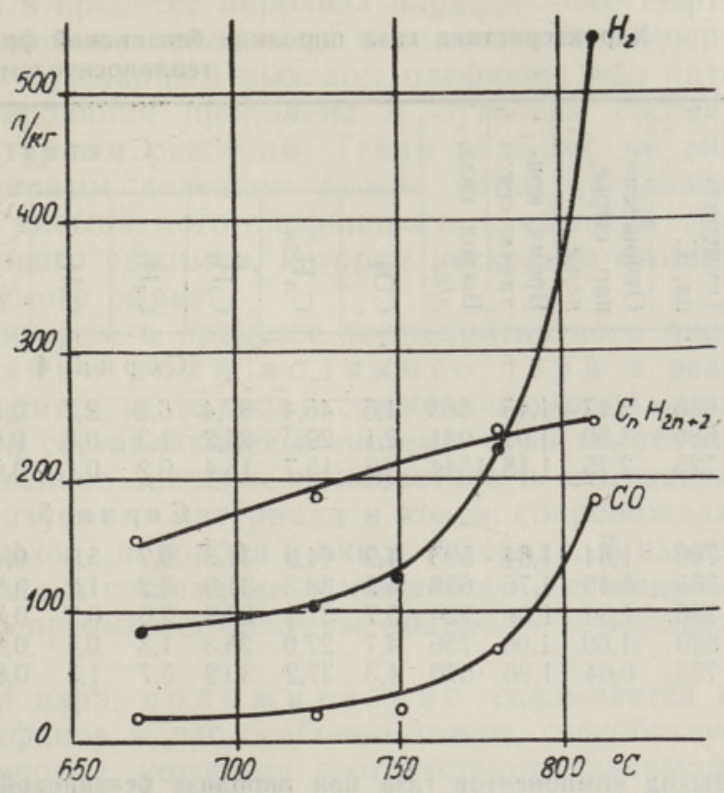

Рис. 7. Выход парафинов, водорода и окиси углерода при пиролизе. Третья серия опытов (см. рис. 4).

Характеристика легких фракций жидкого пиролизата

Таблица 2

\begin{tabular}{|c|c|c|c|c|c|c|}
\hline \multirow{3}{*}{ Компоненты } & \multicolumn{6}{|c|}{ Содержанис и выход, вес.\%, при пиролизе } \\
\hline & \multicolumn{3}{|c|}{$\begin{array}{c}\text { легкого бензина туннельных } \\
\text { печей }\end{array}$} & \multicolumn{3}{|c|}{$\begin{array}{c}\text { бензиновой фракции из } \\
\text { УТТ }\end{array}$} \\
\hline & $95-150^{\circ}$ & $150-200^{\circ}$ & $\begin{array}{l}\text { от пиро- } \\
\text { смолы }\end{array}$ & $95-150^{\circ}$ & $150-200^{\circ} \mid$ & $\begin{array}{c}\text { от пиро- } \\
\text { смолы }\end{array}$ \\
\hline Легкие углеводороды & 11,4 & 4,4 & 5,0 & 1,9 & 0,2 & 0,7 \\
\hline Бензол & 31,4 & 3,5 & 12,6 & 50,2 & 8,1 & 18,6 \\
\hline Метилбензол & 32,6 & 20,8 & 15,8 & 32,2 & 27,5 & 16,6 \\
\hline Метилтиофен & 3,7 & 1,8 & 1,7 & - & 2,2 & 0,5 \\
\hline Этилбензол & 1,6 & 2,0 & 0,9 & 1,4 & 2,0 & 0,9 \\
\hline м-, $n$-Ксилол & 4,8 & 8,7 & 3,3 & 3,3 & 8,4 & 2,8 \\
\hline Пропилбензол & 0,9 & 0,7 & 0,4 & 0,3 & 1,1 & 0,3 \\
\hline o-Ксилол & 2,1 & 5,8 & 1,8 & 2,2 & 6,7 & 2,1 \\
\hline 1-Метил-2-этилбензол & 9,0 & 28,2 & 8,2 & 7,0 & 26,8 & 8,0 \\
\hline $1,2,4$-Триметилбензол & 1,3 & 2,5 & 0,9 & 0,6 & 9,8 & 2,2 \\
\hline 1,2,3-Триметилбензол & 1,0 & 8,6 & 1,9 & 0,9 & 7,2 & 1,8 \\
\hline Индан & $\overline{0}$ & 2,1 & 0,4 & & & \\
\hline Неидентифицированные & 0,2 & 10,9 & 2,0 & & & \\
\hline $\begin{array}{l}\text { Выход фракций от пироли- } \\
\text { зата, вес.\% }\end{array}$ & 37,7 & 17,0 & & 33,7 & 20,8 & \\
\hline
\end{tabular}

Как и в предыдущем случае, жидкий пиролизат, полученный в длительных балансовых опытах, отличается высокой степенью ароматизации. В легкой его части (до $150^{\circ}$ ) суммарное содержание бензола и метилбензола достигает 80 вес. \%. Вторая фракция $\left(150 \div 200^{\circ}\right)$, содержит преимущественно те же компоненты, что и в предыдущем случае. 
Таблица 3

Характеристика газа пиролиза бензиновой фракции из установки с твердым теплоносителем

\begin{tabular}{|c|c|c|c|c|c|c|c|c|c|c|c|c|c|c|c|}
\hline \multirow[b]{2}{*}{ 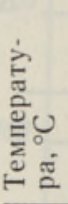 } & \multirow{2}{*}{ 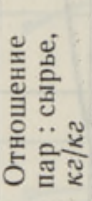 } & \multirow{2}{*}{\multicolumn{2}{|c|}{ 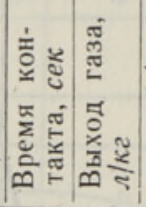 }} & \multicolumn{12}{|c|}{ Состав пирогаза, об. \% } \\
\hline & & & & రీ & $\frac{I^{5}}{I^{5}}$ & $\vec{J}_{0}^{\pi}$ & 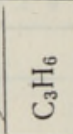 & $\Xi_{U}^{\infty}$ & $0^{5}$ & 8 & \pm & 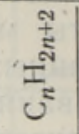 & $\overrightarrow{0}$ & I্ & $z$ \\
\hline & & \multicolumn{14}{|c|}{ Серия 4} \\
\hline $\begin{array}{l}655 \\
680 \\
725\end{array}$ & $\begin{array}{l}3,17 \\
3,50 \\
2,75\end{array}$ & $\begin{array}{l}1,15 \\
1,01 \\
1,18\end{array}$ & $\begin{array}{r}563 \\
921 \\
1544\end{array}$ & $\begin{array}{l}1,5 \\
2,1 \\
3,3\end{array}$ & $\begin{array}{l}46,4 \\
29,3 \\
15,7\end{array}$ & $\begin{array}{l}37,4 \\
27,2 \\
15,4\end{array}$ & $\begin{array}{l}6,3 \\
1,3 \\
0,2\end{array}$ & $\begin{array}{l}2,7 \\
0,8 \\
0,1\end{array}$ & $\begin{array}{l}0,5 \\
0,5 \\
0,6\end{array}$ & $\begin{array}{r}4,0 \\
10,0 \\
14,8\end{array}$ & $\begin{array}{l}19,1 \\
31,5 \\
44,3\end{array}$ & $\begin{array}{l}27,5 \\
24,1 \\
19,3\end{array}$ & $\begin{array}{l}25,0 \\
23,0 \\
18,3\end{array}$ & $\begin{array}{l}2,2 \\
1,0 \\
1,0\end{array}$ & $\begin{array}{l}1,0 \\
2,5 \\
2,0\end{array}$ \\
\hline & & & & & & & Cep & Я Я & & & & & & & \\
\hline $\begin{array}{l}700 \\
755 \\
780 \\
820 \\
755\end{array}$ & $\begin{array}{l}1,64 \\
1,46 \\
1,36 \\
1,69 \\
0,64\end{array}$ & $\begin{array}{l}1,64 \\
1,76 \\
1,08 \\
1,06 \\
1,96\end{array}$ & $\begin{array}{l}595 \\
638 \\
724 \\
756 \\
570\end{array}$ & $\begin{array}{l}4,9 \\
5,2 \\
5,7 \\
4,7 \\
4,3\end{array}$ & $\begin{array}{l}44,9 \\
38,3 \\
31,1 \\
27,0 \\
37,2\end{array}$ & $\begin{array}{l}31,3 \\
31,9 \\
27,8 \\
25,3 \\
30,2\end{array}$ & $\begin{array}{l}9,7 \\
5,2 \\
2,6 \\
1,3 \\
5,7\end{array}$ & $\begin{array}{l}3,9 \\
1,2 \\
0,7 \\
0,4 \\
1,3\end{array}$ & $\begin{array}{l}0,4 \\
0,5 \\
0,5 \\
0,5 \\
0,8\end{array}$ & $\begin{array}{l}3,2 \\
5,0 \\
5,4 \\
5,5 \\
5,0\end{array}$ & $\begin{array}{l}13,6 \\
17,1 \\
21,2 \\
26,7 \\
17,2\end{array}$ & $\begin{array}{l}31,0 \\
31,8 \\
34,1 \\
33,6 \\
32,5\end{array}$ & $\begin{array}{l}27,1 \\
29,5 \\
32,1 \\
32,6 \\
30,0\end{array}$ & $\begin{array}{l}3,8 \\
2,2 \\
2,0 \\
1,0 \\
2,2\end{array}$ & $\begin{array}{l}2,0 \\
2,1 \\
2,0 \\
2,0 \\
3,0\end{array}$ \\
\hline
\end{tabular}

Таблица 4

Выход компонентов газа при пиролизе бензиновой фракции из установки с твердым теплоносителем

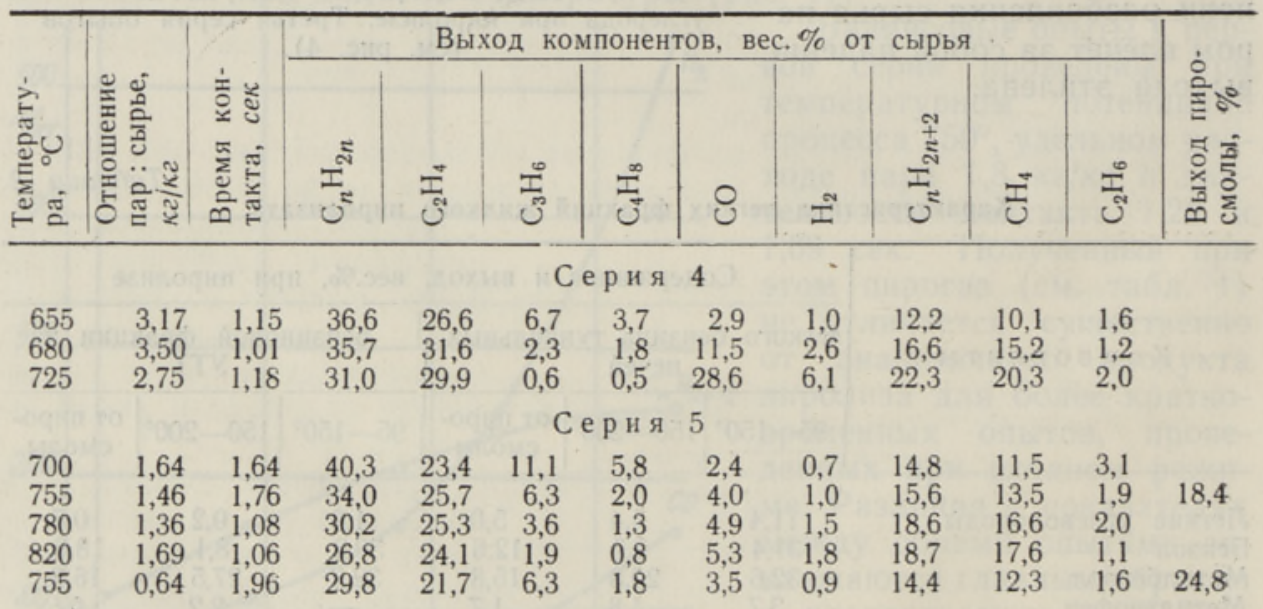

\section{Обсуждение результатов}

Одним из важнейших показателей эффективности процесса пиролиза является выход низших олефинов в составе пирогаза. Он определяется как химической природой исходного сырья, так и термодинамическими и кинетическими условиями ведения процесса - температурным уровнем в реакционной зоне, длительностью контакта реакционной смеси с теплоносителем при данной температуре и парциальным давлением паров органической части сырья. Рассмотрим с этих позиций результаты проведенного исследования.

Для температурно й 3 а в и си мости выхода непредельных углеводородов характерно наличие выраженного максимума. Дальнейшее повышение температуры сверх этого предела обусловливает снижение суммарного выхода олефинов в расчете на сырье и концентрации 
их в смеси. При этом, как и в процессе пиролиза парафинового нефтяного сырья, максимум образования этилена не совпадает по температурной шкале с наибольшим суммарным выходом олефинов, ибо оптимальные температуры формирования пропилена и бутилена соответствуют смягченным температурным режимам. Таким образом, по аналогии с существующим условным делением можно четко установить температурные пределы так называемого олефинового (максимум суммы непредельных) и этиленового режимов, которые несколько отличны для каждого вида пиролизуемого сырья.

Вторым по значению фактором в процессе термоконтактного пиролиза является варьирование доли водяного па ра в реакционной смеси. Его роль сводится не только к снижению парциального давления паров органической составляющей в системе; судя по результатам исследования, существенное значение приобретает и его взаимодействие с углеродом пиролизуемого материала и кокса, сопровождающееся резким увеличением выхода водорода и окиси углерода. В известных условиях баланс водорода в системе не замыкается - суммарный выход его в пиропродуктах превышает ресурсы водорода в исходном бензине.

Возрастаюшая дозировка пара положительно сказывается на формировании и выходе олефинов и, что особенно важно, способствует снижению температурного уровня, которому соответствует максимальный выход низших олефинов. Все же, несмотря на положительную роль добавки водяного пара в кинетическом и термодинамическом аспектах, практическое использование этого фактора в ряде случаев ограничено соображениями экономического характера.

Длительность пребывания паров сырья и продуктов его распада в реакционной зоне в специфически х условиях термоконтактного процесса в кипящем слое (определяющий кинетический фактор при заданном температурном потенциале) непосредственно связана со скоростью подачи и величиной дозировки пара. Поэтому его Барьирование лимитируется как критическим значением скорости псевдоожижения, так и скоростью витания частиц взвешенного материала. Как видно из полученных данных, сокращение длительности контакта ограничивает протекание вторичных реакций и способствует, таким образом, увеличению выхода олефинов - не только этилена, но и пропилена и бутиленов. С изменением времени контакта автоматически изменяется и значение температурного потенциала, соответствующего. максимальному выходу суммы целевых компонентов газа. При условии сохранения необходимой жесткости процесса снижение времени контакта неизбежно сдвигает температурный оптимум в область более высокой температуры. Эта закономерность наблюдается и при пиролизе парафинистого сырья.

Из-за ограниченности полученных данных влияние изученных факторов на выход и состав жидкого пиролизата трудно охарактеризовать так же детально, как процесс формирования газообразной части продуктов пиролиза. Тем не менее снижение продолжительности контакта при неизменном температурном уровне, как показывают полученные данные, влечет за собой увеличение выхода жидкого пиролизата в опытах с неароматизированным сырьем. При исследовании же пиролиза бензина УТТ, то есть ароматизированного исходного сырья, наблюдается обратная зависимость. Интересен также тот факт, что в отличие от процесса пиролиза парафинов в смеси с перегретым водяным паром степень ароматизации легкой части пиросмолы необычно велика. Это можно полностью отнести к вөздействию природы изучаемого сырья. 


\section{Заключение}

Результаты исследования свидетельствуют о высокой эффективности термической конверсии сланцевых бензинов в изученном процессе, особенно с точки зрения получения низших олефиновых углеводородов. Выявленные качественные закономерности воздействия кинетических и термодинамических факторов на формирование углеводородной части «сланцевого» пирогаза мало отличаются от установленных для пиролиза парафинистого нефтяного сырья. Особенностью изученного процесса, обусловленной химической природой сланцевого сырья, является сравнительно интенсивное развитие вторичных реакций с образованием ароматических углеводородов (как легких, так и тяжелых), несмотря на относительно высокую долю водяного пара в реакционной смеси.

\section{Л ИТЕ Р АТ У Р А}

1. А румеель Э., Эйзєн О., Химический состав сланцевых бензинов, Горючие сланцы, вып. 5, Таллин, 1963.

2. Кылль А. Т., Эйзен О. Г., Кивияяхк С. В., Л аус Т. Н., Ранг С. А., О влиянии температуры термического разложения на групповой состав сланцевой смолы, Горючие сланцы. Химия и технология, вып. 3, Таллин, 1959.

3. Л е в а М., Псевдоожижение, М., 1961.

4. Ром анков П. Г., Р ашков ск а я Н. Б., Сушка в кипящем слое, М., 1964.

5. B er a nek J., Chem. Technik, Nr. 2, 71 (1962).

Ннститут химии

Академии наук Эстонской ССР
Поступила в редакцию 18/VII 1966

\section{A. ELENURM, T. LAUS, M. GUBERGRITS}

\section{PÓLEVKIVI KERGEOLI PUROLUUS KEEVKIHIS}

Artiklis esitatakse pōlevkivi kergeōli pürolüüsi tulemused laboratoorsel keevkihiga seadmel ja tehakse nende pōhjal üldistusi temperatuuri, pürolüsaatorisse antava veeauru ja reaktsiooni kontaktiaja mõju kohta pürolüüsile ning gaasiliste küllasturnatute süsivesinike saagisele.

Lähteainena kasutati tunnelahju bensiini kuni $150^{\circ}$ ja tahke soojusekandjaga seadme ōli kuni $200^{\circ}$ keevat fraktsiooni.

Keevkihi tahke faasina kasutati kvartsliiva, mille tera suurus oli $0,40 \div 0,80 \mathrm{~mm}$.

Pürolüüs teostati $640 \div 840^{\circ} \mathrm{C}$ temperatuuris.

\section{A. ELENURM, T. LAUS, M. GUBERGRITS}

\section{SPALTUNG VON BRENNSCHIEFER-LEICHTOOL IN WIRBELSCHICHT}

Im Artikel wird die Spaltung von Brennschiefer-Leichtöl auf einer nach dem Wirbelschichtverfahren arbeitenden Laboratoriumversuchsanlage behandelt.

Als Einsatzprodukt wurden eine bis $150^{\circ} \mathrm{C}$ siedende Fraktion des Tunnelofenbenzins und eine bis $200^{\circ} \mathrm{C}$ siedende Fraktion des in einer mit festem Wärmeträger versehenen Anlage gewonnenen Öls benutzt.

Als feste Phase des Wirbelbettes wurde Quarzsand in der Körnung von $0,40 \div 0,80 \mathrm{~mm}$ gebraucht.

Die Reaktionstemperaturen lagen im Bereich von 640 bis $840^{\circ} \mathrm{C}$.

Auf Grundlage der Versuchsergebnisse werden die Einflüsse von Spalttemperatur, Wasserdampfzusatz und Verweilzeit auf den Spaltprozeß erörtert. 